\title{
The Institutional of Family Planning Program in Decentralization Era in Banyumas District
}

\author{
Dyah Retna Puspita, Rukna Idanati, Nesi Novita Imeldasari \\ Department of Public Administration, Social and Politic FacultySoedirman University \\ Corresponding Author: dyahrpuspita@yahoo.com
}

\begin{abstract}
Since family planning programs is decentralized, the condition of family in Banyumas District was still characterized by a considerable number of children, number of cases of domestic violence as well as the increasing number of divorce. So that, this research was analyse how far the institution of family planning program in this district have attempted to institutionalize the value of small and good quality of family. This research was conducted in three subdistricts by using descriptive qualitative method. The targets were the policy makersof family planning program in district level and sub-district one, community leaders and the participant of family planning program. Data collected by interview and observation and analysed by interactive model. The result were shown that there were some obstacles to realizing this values were: limited authority along with personal staff handle this institution and lack of innovation of the extension agent.
\end{abstract}

Keywords: Institutionalization, small and good quality of family, decentralization era

\section{Introduction}

The implementation of regional autonomy since the enactment of the Local Government Act No. 22 of 1999 on Regional Government revised into Law No. 32 Year 2004 on Regional Government is the beginning of its greater authority of the district / city in managing their resources for the welfare of the society. In addition, public service can be done more quickly and precisely according to the needs of its citizen.

One of this implication was the decentralization of family planning program refer to Presidential Decree Number 103 of 2001 on the Status, Duties, Functions, Authority and Organizational Structures, and the Institute of Non-Departmental Working. This program was no longer carried out under the BKKBN centralistically, but it is now decentralized to region (district). Thus district have independent in dealing with family planning issues, include the bugdet and staff (Puspita, 2012).

In Banyumas Regency, family planning issue has been unified with others such as community empowerment and women empowerment with the title Board of Community and Women Development and Family Planning
("Badan Pemberdayaan Masyarakat, Perempuan dan Keluarga Berencana”) called Bapermas PKB. One of its mission was Achiving Development with Population Perspective and small, happy and prosperousfamily. Unfortunately, until nowthe missionhas not beenaccomplished. It canbe seenfromthe higher average number of children per family in Banyumas compared with figures in the province of CentralJava. Based on this condition, it was interesting to analyse how the family planning instituzionalising process in this district.

\section{Theory Framework}

According to Arturo Israel (1990), institutional is as a process to improve the institution's ability to make effectiveuse of available human resources according to authorities. Uphoff (1986) said that some kinds of institutions have an organizational form with roles and structures, whereas others exist as pervasive influenced on behaviour. Esman (in Eaton, 1986) state that institutionwas the result ofthe process ofinstitutionalization. The goal was build an organization that can live effectively and can support innovation and social change. Processes that occur in the institutional 
development was generic where social innovation was not being forced on the public. So inthe model of institutional building, institutionswas placed as a formal organization that roduces change and protect the network changes as well.

According to Esman (in Eaton, 1986), institutional process has five criterias: (1) technical competence, (2) normative commitment, (3) innovative support, (d) environment image) and (5) spread effect. Technical competence was a competence to increase their staff 's competence to give innovation suitable with the social need. Normative competence refer to competence to make the staff become understand and support the vision and mission's organization. Innovative support was institution's competence to create innovation regularly to answer their social need. Environmental image was competence in showing their institution's existence as a valuable institution for their environment. While spread effect was about how far the innovation has been accepted and supported by target group.

\section{Research Methodology}

This research was condacted in Banyumas district, especially in three sub-districts: East Purwokerto, Kembaran and Sumbang which selected purposively. Informants were chosen by purposive sampling. They were policy makers whose involved in decision making process of the Bapermas PKB and family planning program. Another informants were active couples who utilized family planning service in their village and also informal leaders. Five aspects were focused in this research which develop with descriptive qualitative approach. Data was collected by depth interview, observation and documentary and then analysed by interactive model.

\section{Result And Discussion}

\subsection{Technical Capabilities}

Technical capability was ability to provide technical services to the community in the form of innovations with increasing competence (Esman in Eaton, 1986:41). Its aspects were the organizational structure, duties and functions of each member in Bapermas PKB Banyumas. The organizational structure shows shape of the organization and relationship between parts and members of the organization.

There were four divisions in Bapermas PKB: (1) Division of Empowerment and village administration Divion, (2) Division of Economic Empowerment and Natural Resouces and Appropriate Technology, (3) Division of Women Empowerment and Child Protection, and (4) Division of Family Planning and Family Welfare. Thus it was appear that Bapermas PKB Banyumas responsible for many areas in empowering where family planning was only a part of them. Division of Family Planning and Welfare Family was devided into two sections were: (1) Sub-division of Family Planning and Reproductive Health and (2) Sub-division of Family Welfare and Family Empowerment. Division of Family Planning and Family Welfare led by a Head of Division, while each subdivision led by Head of Sub-division. There were only five staffs handle both sub-division. Thus, the field of family planning was only taken care of 8 staffs. This very few number of staff should be responsible for development of family planning and family welfare in 27 sub-districts in Banyumas District.

The main task of Sub-division of Family Planning and Family Welfare was to formulate policies of family planning programs, population, family support and economic empowerment of the family. Meanwhile the main task of Sub- 
division of Family Welfare and Family Empowerment was improving family welfare. The function of Head of Family Planning and Family Welfare is to help leaders to formulate policy, while Head of Sub Division was in coordinating and coaching. According to the informants, they understand about their job and responsible. It can be seen from long time they placed their position.

\subsection{Normative Commitment}

Innovative supporting associate to existing programs in Division of Family Plannning. It can be seen from type of programs offered to the community and ability to determine the targets of the program and allocate and distribute the resources. Interviews showed that programs which has been implemented in all sub-division was directed to encourage the establishment of the organization's mission. Sub-division of Family Planning and Reproductive Health has several programs include counseling, provision of contraceptives, contraceptive installation and provision of data and information. Meanwhile, the program of Sub-division Family Welfare and Family Empowerment were supervising three types of family whose having children under 5 years old, teen-aged children and parent who lived together. Another program was increase family income by providing capital assistance.

\subsection{Environment Image}

Environmental image associated with the institution's ability to survive. The strategy was done by introducing a new program, fostering family planning acceptors and collaboration with other institutions. Introducing a new program was addressed to correct or improve the previous program. This was done by empowering cadres in order to socialize this to the families in each neighborhood. Another ways were optimize various types of communication such as counseling, group communication and mass communication. The other one was playback movies in the open field. Acceptors - especially poor one- also having attention through free services for using long-term contraseption methode such vasectomi and tubectomi. Another efforts to maintain the image of the organization was conduct cooperation with other agencies. For example: TNI-ABRI, women organizations and informal leaders. This cooperation may include joint counseling and contraceptive services free.

\subsection{Effects Distribution}

Distribution effects associated to what extent society has accepted and applied family planning value. It can be seen from their knowledge of family planning programs and their opinions about the suitability of the program with the aim of achieving the program. According to the informants, most of their society has already know about family planning program. However, in reality their behavior is not entirely appropriate. It was appear from the number of families who have more than two children with a space-range was too close (about 2-3 year).

\subsection{Discussion}

From the above it was appear that the values of family planning in Banyumas have not been institutionalized due to the limited authority of the Division of Family Planning because it was only a part in Bapermas PKB. These results reinforce previous findings in the same institution where gender mainstreaming program has not been done due to the limited budget (Septiyani, 2009 ).

Institutionalization process was a heavy and long process. It was also happen in disaster management which handled by Board of Natural Disaster Management in Banyumas District (Iskandar, 2012). Azad and Faraj (2009) who examined institutionalization outcomes as construction of actor-networks and 
institutionalizing practices as enactment of actornetwork reconfiguration provide evidence of black-box status for some E-Gov functions and situated institutionalization for others. They thereby extend the research on E-Gov postadoption and post-implementation behaviors by providing early evidence of generic institutionalization measures and institutionalizing practices. While Schuppan (2009) addresses the different institutional and cultural contexts which must be considered when implementing E-Government in sub-Saharan Africa. Although E-Government is a global phenomenon, simply transferring ICT solutions and related organizational concepts from developed to developing countries seems inappropriate.

E-Government undoubtedly has the potential to reduce administrative and development problems. However, it is obvious that compared to developed countries, additional effort is necessary when implementing EGovernment in developing countries. More than in developed countries, the different initial institutional, cultural, and wider administrative contexts must be considered to avoid unintended effects. It is oversimplifying the issue to merely state that E-Government projects fail in Africa and other developing regions. Although EGovernment in African countries lags far behind developed countries, this should be considered more as a state failure or lack of capacity in general. In particular, the different administrative contexts and rationalities must be taken into an account when implementing E-Government projects and strategies. Therefore, especially for African countries, a context-oriented approach seems to be a more promising route to the successful implementation of E-Government. The results of this approach may not seem ambitious from a western perspective, but could contribute to the solution of real-life and development problems in African societies. From this some research it can be shown that institutionalization is a process which need attention in many aspects, not only internal aspect but also external one.

\section{Conclusion}

On the technical capability criterion it was appears that officials have been trying to carry out their duties properly. However, this is often constrained by limitations of authority and number of staff. In fact, their work areas was very broad and the number of extension agents was diminish. As a result, their work performance become ineffective. On normative commitment criteria, it was appear that the confidence of the officials of Division of Family Planning Bapermas PKB has already quite high. This encourages them trying to always prioritize the interests of their organization. On innovative encouragement criteria, it was appears that although the programs created by the division of family planning has been pretty good, but it has not been able tolowering the TFR as targeted. On the spread effect criteria, it was appear that in general society has been known about family planning even though not evently.

\section{References}

1) Azad,Bijan \& Samer Faraj. (2009). EGovernment Institutionalizing Practices of a Land Registration Mapping System. Government Information Quarterly. 26 (1), Januari 2009, .http://www.sciencedirect.com/ science/article/pii/S0740624X08001196.

Access: 5 Mei 2014.

2) Eaton, Joseph W. (1986). Pembangunan Lembaga dan Pembangunan Nasional. Jakarta: UI-Press. 
3) Iskandar, Muhammad. (2011). Kapasitas Kelembagaan Badan Penanggulangan Bencana Daerah (BPBD) Banyumas dalam Pencegahan dan Pelaksanaan Penanggulangan Bencana di Kabupaten Banyumas. Skripsi. FISIP Universitas Jenderal Soedirman.

4) Israel, Aurto. (1990). Pengembangan Kelembagaan Pengalaman Proyek-Proyek Bank Dunia. Jakarta: LP3S

5) Miles, Mathew B and Michael Huberman. (2007). Analisis Data Kualitatif. Jakarta: Universitas Indonesia

6) Schuppan, Tino. (2009). E-Government in developing countries: Experiences from subSaharan Africa. Government Information Quarterly, 26 (1), January, 118-127. http://www.sciencedirect.com/ science/journal/0740624X/26/1. Access: 4 Mei 2014.

7) Septiyani, Pridiyah. (2009). Implementasi Program Penguatan Kelembagaan Pengarusutamaan Gender dan Anak di Kabupaten Banyumas. Skripsi. FISIP Universitas Jenderal Soedirman. 